\title{
Analisis Kelayakan LoRa Untuk Jaringan Komunikasi Sistem Monitoring Listrik Di Politeknik Negeri Samarinda
}

\author{
Ayub Repa Batong ${ }^{1}$, Prihadi Murdiyat ${ }^{1}$, Abdul Hamid Kurniawan ${ }^{1}$, \\ ${ }^{1}$ Jurusan Teknik Elektro, Politeknik Negeri Samarinda \\ pmurdiyat@polnes.ac.id
}

\begin{abstract}
Abstrak- Di Politeknik Negeri Samarinda (Polnes) akan dibangun sistem monitoring energi listrik terpadu. Untuk membangun jaringan komunikasinya diperlukan teknologi komunikasi yang dapat bekerja dengan baik. Mempertimbangkan luas Polnes sebesar 10 hektar dan jarak antara gedung yang cukup jauh, salah satu teknologi radio yang dapat digunakan adalah LoRa (Long Range). LoRa diklaim dapat mencapai jarak hingga 20-30 kilometer pada kondisi line of sight (LoS). Namun, kampus Polnes yang berbukit-bukit dan penuh gedung bertingkat bisa menyulitkan jaringan komunikasi yang akan dibentuk. Pada penelitian ini dilakukan pengukuran link untuk mengetahui layak tidaknya LoRa digunakan pada sistem monitoring di Polnes. Kelayakan dinilai berdasar parameter RSSI, SNR, dan packet loss (PL) yang diperoleh dari hasil pengukuran pada unit receiver yang diletakkan dalam beberapa gedung, dengan sinyal yang dipancarkan dari unit sender yang dipasang di luar gedung Laboratorium Teknik Elektro. Penelitian dilakukan dengan menggunakan dua jenis frekuensi operasi LoRa yaitu $433 \mathrm{MHz}$ dan 915 MHz. Dari hasil pengukuran pada frekuensi $433 \mathrm{MHz}$ maupun $915 \mathrm{MHz}$, nilai RSSInya lebih besar dari -120 dB, SNR lebih besar dari -20 dB, dan nilai PLnya lebih kecil dari 3\%. Ini menunjukkan bahwa LoRa layak untuk digunakan sebagai jaringan komunikasi sistem monitoring. Selain itu, juga diperoleh bahwa LoRa dengan frekuensi kerja $433 \mathrm{MHz}$ memmpunyai performa yang lebih baik dibanding LoRa dengan frekuensi 915 MHz. Begitu juga, hasil yang diperoleh dari antena Yagi-Uda umumnya lebih baik dan konsisten dibanding hasil yang diperoleh dari antena rubber duck.
\end{abstract}

Kata kunci : LoRa, RSSI, SNR, packet loss.

\section{Pendahuluan}

Ketiadaan alat ukur energi listrik di tiap gedung dalam kampus Politeknik Negeri Samarinda menyebabkan diperlukannya system yang mampu memberikan data energi listrik tersebut. Sebuah sistem monitoring nirkabel yang dikembangkan dari penelitian dosen dan mahasiswa sedang dibangun. Tidak hanya untuk keperluan monitoring listrik, sistem ini nantinya akan dikembangkan untuk memonitor dan mengatur sumber daya lain seperti penggunaan air bersih, sumber energi surya, dan lain sebagainya.

Sistem monitoring terdiri dari sensor node $(\mathrm{SN})$, gateway, internet dan server. SN akan diletakkan berdekatan dengan titik yang akan diukur. Sensor pada SN akan mengukur parameter, mengubah menjadi data digital dan mengirimnya ke sink / gateway. Sink/gateway berfungsi untuk mengumpulkan data yang dikirim oleh SN dan meneruskanya ke server melalui jaringan internet dalam kampus. Website yang dapat menampilkan informasi parameter listrik seperti daya, energi, dan lainnya dapat diakses oleh pihak otoritas Politeknik.

Untuk keperluan monitoring energy listrik, SN akan diletakkan di dekat panel utama di setiap gedung di Politeknik. Jaringan komunikasi antara sejumlah SN dengan gateway rencananya akan menggunakan teknologi long range (LoRa), yang merupakan salah satu kandidat kuat komunikasi jaringan nirkabel untuk internet of things (IoT).

Pada pengukuran di atas laut dengan kondisi line of sight $(L o S)$ di mana tidak terdapat penghalang antara pemancar dengan penerima yang dilakukan pada [1], diperoleh bahwa LoRa mampu berkomunikasi dalam jarak yang jauh hingga 30 km. Namun, di area kampus Politeknik Negeri Samarinda kemungkinan hal itu sulit dicapai. Banyaknya bangunan yang tingginya bervariasi dan kondisi tanah yang berbukit-bukit sangat tidak memungkinkan untuk mencapai kondisi LoS. Karena itu, pengukuran kemampuan LoRa pada kondisi tersebut diperlukan untuk melihat efektifitasnya dalam membentuk jaringan komunikasi yang diperlukan.

Hasil yang diperoleh akan menjadi pertimbangan apakah LoRa akan digunakan dalam system monitoring. Jika digunakan, juga akan menjadi referensi pada penelitian berikutnya tentang bagaimana model topologi jaringan yang sesuai dengan kondisi lingkungan di Politeknik Negeri Samarinda.

Di Indonesia, transceiver LoRa yang diperjual belikan bekerja pada frekuensi $433 \mathrm{MHz}$ atau $915 \mathrm{MHz}$. Menurut Peraturan Menkominfo no 1 tahun 2019, alokasi frekuensi yang digunakan untuk LoRa di Indonesia adalah $915 \mathrm{MHz}$. Maka pengukuran dilakukan pada frekuensi ini. Adapun pengukuran pada frekuensi $433 \mathrm{MHz}$ dalam penelitian ini digunakan sebagai pembanding.

\section{TINJAUAN PUSTAKA}

\section{A. LoRa}

LoRa adalah teknologi nirkabel yang digunakan untuk membuat link komunikasi jarak jauh. Ketika banyak teknologi nirkabel lama menggunakan modulasi frequency shift keying (FSK) sebagai lapisan fisik karena merupakan modulasi yang sangat efisien untuk mencapai daya rendah, LoRa menggunakan modulasi chirp spread spectrum, yang mempertahankan karakteristik daya rendah yang sama dengan 
modulasi FSK, tetapi secara signifikan meningkatkan jangkauan komunikasi [1].

Jangkauan komunikasi LoRa sangat jauh hingga mencapai beberapa puluh kilometer. Sehingga komunikasi antara sebuah stasiun dengan gateway-nya dapat dilakukan hanya dengan satu jangkauan saja. Jangkauan sangat tergantung pada lingkungan atau penghalang di lokasi tersebut. Pada Gambar 1 ditunjukkan peta jaringan Proximus di Belgia, yang menggunakan teknologi LoRa. Dengan jumlah infrastruktur minimal, seluruh negara dapat dengan mudah dijangkau [2].

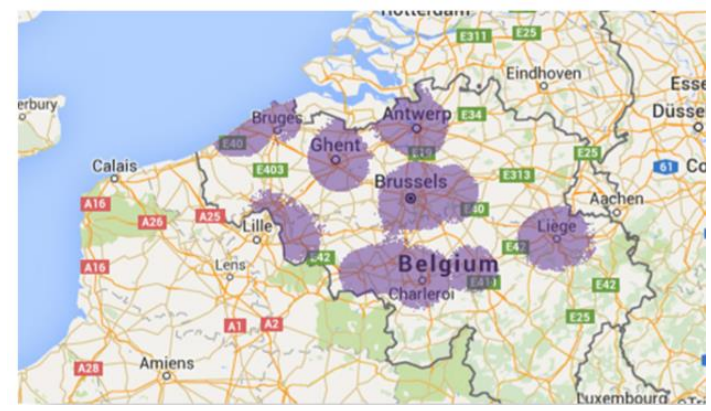

Gambar 1. Peta jaringan Proximus [2]

\section{B. LoraWAN}

LoRaWAN adalah spesifikasi jaringan Low Power Wide Area Network (LPWAN) yang kembangkan oleh LoRa Alliance. Sesuai 7 layer OSI, LoRa terletak pada bagian physical layer, sementara LoRaWAN, yang mendefinisikan protokol komunikasi dan arsitektur sistem untuk jaringan, berada pada lapisan-lapisan di atasnya. Arsitektur jaringan LoRaWAN ditunjukkan dalam Gambar 2.

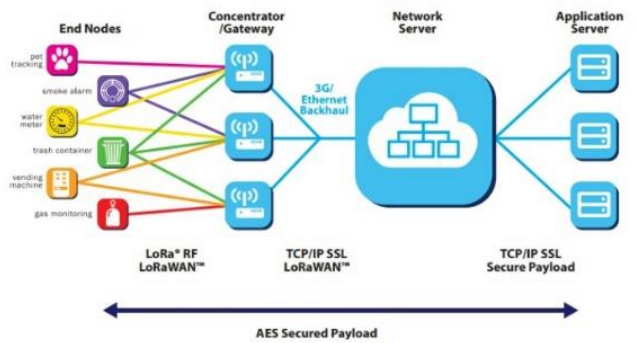

Gambar 2. Arsitektur jaringan LoRaWAN [2]

Data dibangkitkan oleh end node/sensor node dari hasil pengukurannya terhadap parameter yang diinginkan. Kemudian, data dikirim ke gateway melalui jaringan radio LoRa. Selanjutnya gateway akan meneruskan data ke server melalui fasilitas 3G, Ethernet atau fasilitas komunikasi public lainnya. Dalam jaringan internet, terdapat network server yang mengatur ke server aplikasi mana data dikirim. Protokol dan arsitektur jaringan LoRaWAN memiliki pengaruh yang besar terhadap masa pakai baterai dari sensor node, kapasitas jaringan, kualitas layanan, keamanan, dan beragam aplikasi yang dilayani oleh jaringan [2].

\section{Keunggulan Teknologi LoRa}

LoRa memiliki kelebihan dibandingkan dengan jenis komunikasi lainnya seperti seluler, Bluetooth maupun WIFI. Kemampuan komunikasi jarak jauh seperti seluler, namun berdaya rendah seperti Bluetooth, menyebabkan penggunaanya sangat cocok untuk perangkat sensor yang dioperasikan tahunan dengan sumber daya baterai dan pada cakupan area yang luas. LoRa mempunyai keterbatasan kecepatan transmisi data yaitu antara 0.3 kbps hingga $50 \mathrm{kbps}$. Walaupun begitu tidak akan menjadi masalah selama data yang dikirimkan berukuran kecil [3]. Aplikasi seperti ini cocok digunakan untuk berbagai macam jaringan sensor nirkabel (wireless sensor network/WSN).

Komunikasi pada LoRa menggunakan protokol dan media komunikasi radio yang berbeda dengan protokol dan media komunikasi yang digunakan oleh jaringan internet. Maka agar data yang diterima dari sensor node bisa sampai ke server aplikasi yang diinginkan, gateway harus menjadi interface dari kedua jenis jaringan ini [4].

\section{Pengujian Sinyal Radio LoRa}

Sebelum membuat jaringan komunikasi, pada umunya perlu dilakukan pengukuran terhadap kelayakan suatu teknologi radio. Demikian halnya dengan LoRa. Untuk membangun sistem transmisi data yang reliable beberapa parameter yang diukur antara lain adalah: RSSI, SNR, dan packet loss [5].

\section{1). RSSI}

Received Signal Strength Indicator atau RSSI merupakan indikator kekuatan sinyal terima [6]. RSSI ini merupakan perkiraan level daya terukur yang diterima dari klien RF yang dalam kebanyakan kasus menunjukkan seberapa baik radio tertentu dapat mendengar radio klien yang terhubung jarak jauh.

\section{2). SNR}

Signal to Noise Ratio atau SNR adalah parameter yang dapat menentukan kualitas dari sebuah sinyal yang terganggu oleh derau [5]. SNR ialah perbandingan antara daya sinyal yang diinginkan dengan daya sinyal yang tidak diinginkan, yang dihasilkan oleh noise. SNR menyatakan kualitas sinyal informasi yang diterima pada sistem transmisi. SNR juga merupakan batas ambang sinyal analog yang masih dapat diterima. Semakin besar nilai SNR maka kualitas sinyal semakin bagus. Noise yang bernilai besar akan menyebabkan nilai SNR yang semakin kecil. Semakin dekat jarak transmisi, maka akan semakin besar pula kekuatan SNR begitu pula sebaliknya [7].

\section{3). Packet Loss}

Packet Loss adalah persentase paket yang hilang selama mentransmisikan data. Hal ini disebabkan oleh banyak faktor seperti penurunan sinyal dalam media jaringan, kesalahan perangkat keras jaringan, atau juga radiasi dari lingkungan sekitar [8].

Packet loss juga merupakan suatu parameter yang menggambarkan suatu kondisi yang menunjukkan jumlah total 
paket yang hilang, dapat terjadi karena collision dan congestion pada jaringan dan hal ini berpengaruh pada semua aplikasi karena retransmisi akan mengurangi efisiensi jaringan secara keseluruhan meskipun jumlah bandwidth cukup tersedia untuk aplikasi-aplikasi tersebut. Umumnya perangkat jaringan memiliki buffer untuk menampung data yang diterima [9]. Kategori packet loss dapat dilihat pada Tabel 1.

TABEL 1

KATEGORI PACKET LOSS [9]

\begin{tabular}{cc}
\hline \hline Kategori Degradasi & Packet Loss \\
\hline Sangat Bagus & $0 \%$ \\
Bagus & $3 \%$ \\
Cukup & $15 \%$ \\
Buruk & $25 \%$ \\
\hline
\end{tabular}

\section{E. Arduino Uno}

Arduino Uno adalah board mikrokontroler berbasis ATmega328. Memiliki 14 pin digital, di mana 6 pin input tersebut dapat digunakan sebagai output PWM, 6 pin input analog, $16 \mathrm{MHz}$ osilator kristal, koneksi USB, jack power, ICSP header, dan tombol Reset [10]. Tampilan board Arduino Uno ditunjukkan dalam Gambar 3, sedangkan spesifikasinya ditunjukkan dalam Tabel 2.

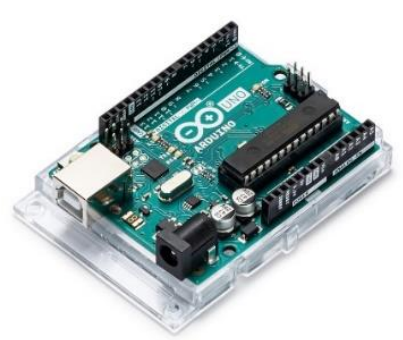

Gambar 3. Tampilan Arduino Uno [10]

TABEL 2

SPESIFIKASI ARDUINO UNO [10]

\begin{tabular}{ll}
\hline \hline Microcontroller & ATmega328P \\
Operating Voltage & $5 \mathrm{~V}$ \\
Input Voltage (recommended) & $7-12 \mathrm{~V}$ \\
Input Voltage (limit) & $6-20 \mathrm{~V}$ \\
Digital I/O Pins & 14 (of which 6 provide PWM \\
& output) \\
PWM Digital I/O Pins & 6 \\
Analog Input Pins & 6 \\
DC Current per I/O Pin & $20 \mathrm{~mA}$ \\
DC Current for 3.3V Pin & $50 \mathrm{~mA}$ \\
Flash Memory & $32 \mathrm{~KB}$ (ATmega328P) of which 0.5 \\
& KB used by bootloader \\
SRAM & $2 \mathrm{~KB}$ (ATmega328P) \\
EEPROM & $1 \mathrm{~KB}$ (ATmega328P) \\
Clock Speed & $16 \mathrm{MHz}$ \\
LED_BUILTIN & 13 \\
Length & $68.6 \mathrm{~mm}$ \\
Width & $53.4 \mathrm{~mm}$ \\
Weight & $25 \mathrm{gr}$ \\
\hline
\end{tabular}

\section{F. Arduino Nano}

Arduino Nano adalah salah satu papan pengembangan mikrokontroler yang berukuran kecil, lengkap dan mendukung penggunaan breadboard. Arduino Nano diciptakan dengan basis mikrokontroler ATmega328 (untuk Arduino Nano versi 3.x) atau ATmega 168 (untuk Arduino versi 2.x) [10]. Arduino Nano kurang lebih memiliki fungsi yang sama dengan Arduino Duemilanove, tetapi dalam paket yang berbeda. Arduino Nano tidak menyertakan colokan DC berjenis Barrel Jack, dan dihubungkan ke komputer menggunakan port USB Mini-B. Bentuk Arduino Nano ditunjukkan dalam Gambar 4, dan spesifikasinya diberikan dalam $\underline{\text { Tabel } 3}$.

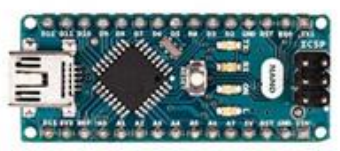

Gambar 4. Tampilan Arduino Nano [10]

TABEL 3

SPESIFIKASI ARDUINO NANO [10]

\begin{tabular}{ll}
\hline \hline Microcontroller & ATmega328 \\
\hline Architecture & $\mathrm{AVR}$ \\
Operating Voltage & $5 \mathrm{~V}$ \\
Flash Memory & $32 \mathrm{~KB}$ of which 2 KB used by \\
SRAM & bootloader \\
Clock Speed & $2 \mathrm{~KB}$ \\
Analog IN Pins & $16 \mathrm{MHz}$ \\
EEPROM & 8 \\
DC Current per I/O Pins & $1 \mathrm{~KB}$ \\
Input Voltage & $40 \mathrm{~mA}$ (I/O Pins) \\
Digital I/O Pins & $7-12 \mathrm{~V}$ \\
PWM Output & $22(6$ of which are PWM) \\
Power Consumption & 6 \\
PCB Size & $19 \mathrm{~mA}$ \\
Weight & $18 \mathrm{x} 45 \mathrm{~mm}$ \\
Product Code & $7 \mathrm{~g}$ \\
\hline
\end{tabular}

\section{G. Antena Slim Jim}

Antena yang mempunyai pola radiasi omni directional ini, umumnya dicirikan sebagai antena dipole vertikal terlipat. Efisiensi radiasinya 50\% lebih baik daripada antena Ground Plane karena radiasi sudutnya yang rendah. Nama Slim Jim berasal dari konstruksi rampingnya yang menggunakan tipe $\mathbf{J}$ [11]. Bentuk antena Slim Jim ditunjukkan dalam Gambar 5.

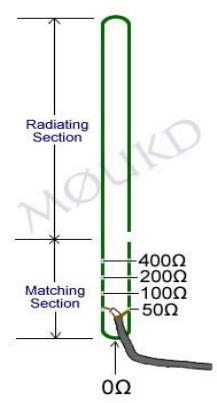

Gambar 5. Bentuk antena Slim Jim [11] 


\section{H. Antena Yagi}

Sejak ditemukan oleh S. Uda dan Hidetsugu Yagi di Universitas Tohoku pada tahun 1926, antena Yagi-Uda, yang sering disebut antena Yagi, banyak sekali digunakan pada komunikasi radio amatir dan antena penerima televisi. Kelebihan antena Yagi di antaranya adalah konstruksinya yang mudah, mempunyai direktivitas dan gain yang tinggi [12].

Antena yang mempunyai pola radiasi uni-directional ini umumnya terdiri dari sebuah reflektor, sebuah driven element, dan beberapa direktor yang dirangkai pada sebuah boom, seperti ditunjukkan pada Gambar 6.

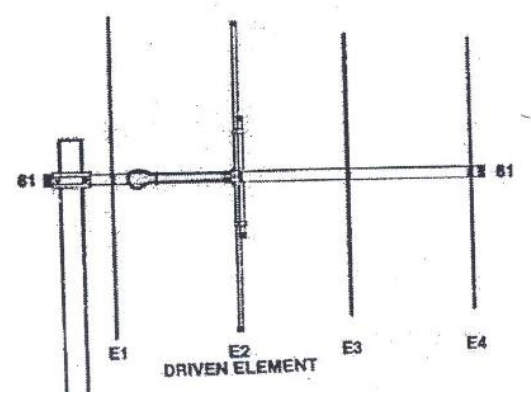

Gambar 6. Tampilan antena Yagi-Uda 4 elemen [12]

Adapun fungsi dari tiap-tiap elemen tersebut adalah sebagai berikut:

1). Driven merupakan bagian paling penting dari sebuah antena Yagi karena elemen inilah yang mengubah sinyal listrik yang dibangkitkan pemancar menjadi gelombang elektromagnetik yang dipancarkan melalui udara. Kabel antena dihubungkan dengan keluaran pemancar melalui kabel antena.

2). Reflektor, sesuai dengan namanya berfungsi sebagai pemantul. Elemen reflektor ditempatkan dibelakang elemen driven dan dibuat lebih panjang dari elemen driven. Umumnya mempunyai panjang $0,55 \lambda$ (panjang gelombang).

3). Direktor berfungsi sebagai adalah pengarah radiasi gelombang radio. Ukurannya $5 \%$ lebih pendek daripada elemen driven. Penambahan batang direktor akan menambah gain antena, namun akan membuat pola pengarahan antena menjadi lebih sempit. Semakin banyak jumlah direktor, maka semakin sempit sudut pengarahannya.

4). Boom, adalah tempat untuk memasang ketiga elemen tersebut.

\section{Antena Rubber Duck}

Banyak jenis antena yang digunakan secara komersial digolongkan sebagai rubber duck. Antena ini sebenarnya adalah antena monopole dengan load induktif yang dilingkupi dengan bahan plastic atau karet [13]. Antena-antena rubber duck banyak digunakan pada radio komunikasi mobile karena murah, berukuran relatif kecil, dan mempunyai pola radiasi omnidirectional. Bentuk antena rubber duck ditunjukan dalam Gambar 7.

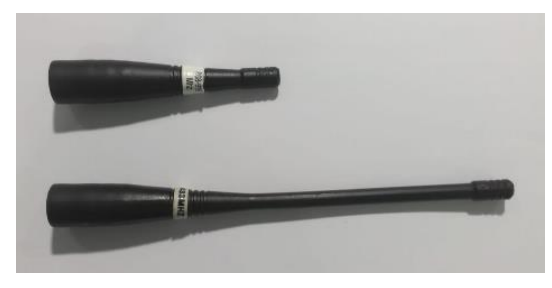

Gambar 7. Bentuk fisik antena rubber duck

\section{METODE PENELITIAN}

\section{A. Gambaran Umum Sistem}

Pada penelitian ini, system yang digunakan untuk melakukan pengukuran link LoRa ditunjukkan dalam Gambar 8. Board Arduino Nano pada sender akan membangkitkan paket dengan no 1 hingga 1000, dan diulang secara terus menerus. Oleh transmitter LoRa pada unit sender, paket data yang diterima mengalami proses modulasi dan akan dipancarkan melalui antena sender. Ketika data diterima oleh unit receiver LoRa, parameter RSSI, SNR, dan PL akan dihitung oleh program dalam Arduino Uno dan ditampilkan pada layar LCD.

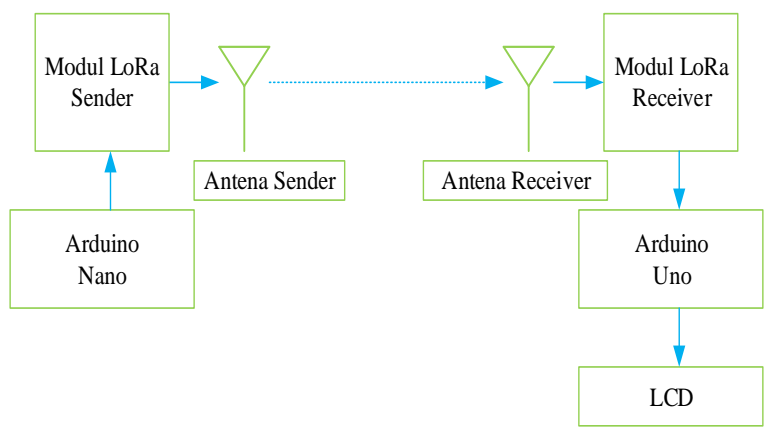

Gambar 8. Gambaran umum sistem pengukuran

Perangkat yang diperlukan untuk mengukur link komunikasi dirancang bangun oleh penulis sendiri. Perangkat tersebut adalah: sender LoRa dan receiver LoRa, antena Slim Jim, antena Yagi-Uda. Sementara itu, antena rubber duck menggunakan yang sudah tersedia di laboratorium mikroprosesor.

\section{B. Waktu dan Lokasi}

Pembuatan perangkat dilaksanakan pada bulan Mei hingga Juni 2020, bertempat di Laboratorium Mikroprosesor dan Laboratorium Listrik Dasar Jurusan Teknik Elektro Politeknik Negeri Samarinda. Pengukuran dilakukan pada bulan Juli 2020 di lingkungan kampus Politeknik Negeri Samarinda.

\section{Perancangan Rangkaian Arduino dan LoRa $433 \mathrm{MHz}$}

Untuk unit sender dengan LoRa 433 MHZ, board mikrokontroler yang digunakan adalah Arduino Nano, sedangkan untuk unit receiver digunakan Arduino Uno. Pertimbangannya hanya karena ketersediaan perangkat yang 
dimiliki oleh penulis, juga kemudahan untuk mengkoreksi koneksi yang lebih banyak, karena harus mengontrol LCD.

Koneksi antara Arduino Nano dengan transceiver LoRa $433 \mathrm{MHz}$ pada rangkaian sender ditunjukkan pada Gambar 9, sementara koneksi antara Arduino Uno dengan transceiver LoRa 433 MHz ditunjukkan dalam Gambar 10.

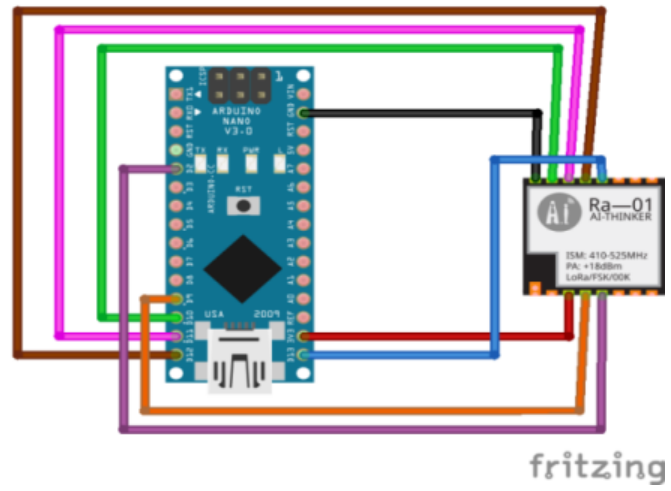

Gambar 9. Rangkaian sender LoRa $433 \mathrm{MHz}$

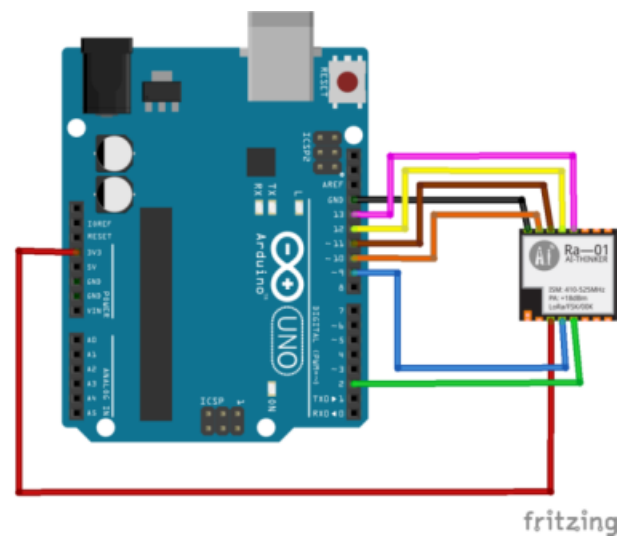

Gambar 10. Rangkaian receiver LoRa $433 \mathrm{MHz}$

\section{Perancangan Rangkaian Arduino dan LoRa $915 \mathrm{MHz}$}

Terminal-terminal pada transceiver LoRa $915 \mathrm{MHz}$ terletak pada pin-pin yang berbeda dengan terminal pada transceiver LoRa $433 \mathrm{MHz}$. Akibatnya koneksi antara transceiver LoRa $915 \mathrm{MHz}$ dengan Arduino Uno maupun Arduino Nano, juga berbeda. Koneksi antara transceiver LoRa $915 \mathrm{MHz}$ dengan Arduino Nano pada sender $915 \mathrm{MHz}$ ditunjukkan dalam Gambar 11, sedangkan koneksi antara transceiver LoRa $915 \mathrm{MHz}$ dengan Arduino Uno pada receiver $915 \mathrm{MHz}$ ditunjukkan dalam Gambar 12.

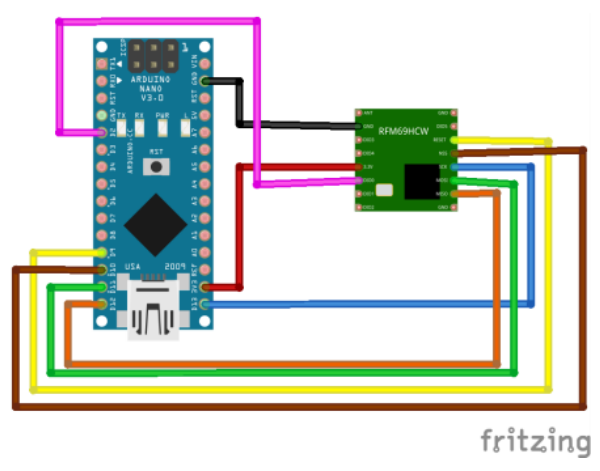

Gambar 11. Rangkaian sender LoRa 915 MHz

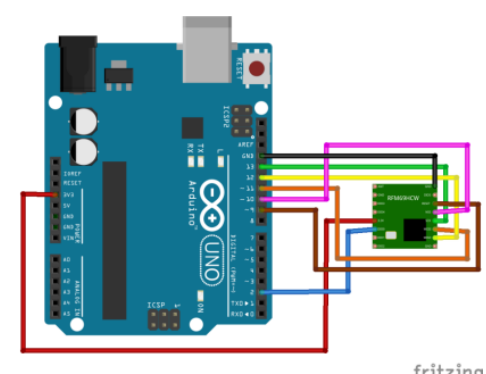

Gambar 12. Rangkaian receiver LoRa $915 \mathrm{MHz}$

\section{E. Perancangan Display LCD Dan Modul I2C}

Untuk menghubungkan display LCD dengan board Arduino umumnya digunakan banyak terminal. Ini karena bentuk komunikasi yang digunakan adalah paralel. Untuk mengurangi penggunaan terminal Arduino, dapat digunakan modul I2C. Modul yang dapat mengubah komunikasi paralel menjadi serial dengan format $\mathrm{I} 2 \mathrm{C}$ ini mempunyai tampilan seperti pada Gambar 13 .

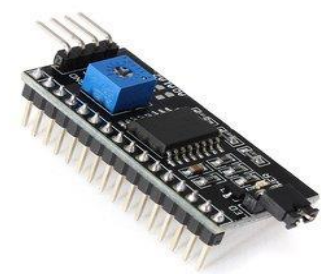

Gambar 13. Tampilan modul I2C

Dengan menggunakan modul I2C, maka hanya diperlukan empat terminal saja untuk menghubungkan display LCD dengan board Arduino Uno. Koneksi antara LCD yang telah dipasang modul I2C dengan Arduino Uno ditunjukkan dalam Gambar 14. 


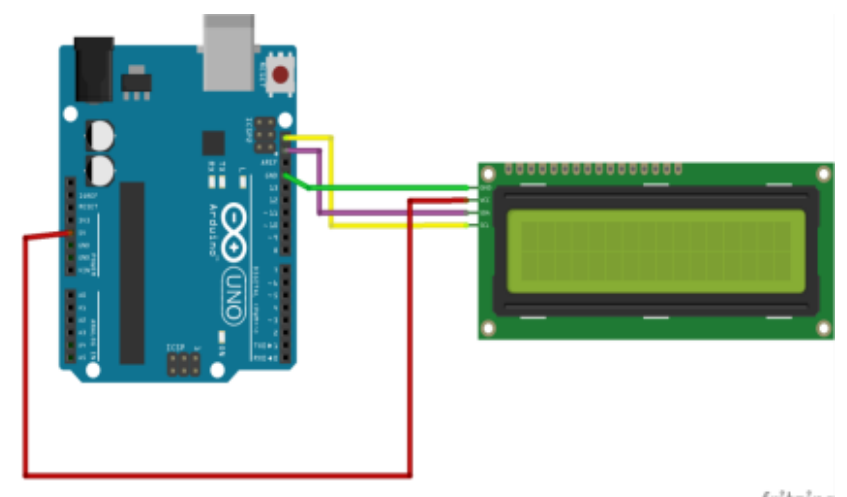

fritzing

Gambar 14. Rangkaian display LCD

\section{F. Perancangan Antena Sender}

Antena yang digunakan untuk perangkat sender $433 \mathrm{MHz}$ dan $915 \mathrm{MHz}$ menggunakan antena jenis Slim Jim yang merupakan antena dengan pola radiasi omnidirectional (ke segala arah), yang dapat menerima gelombang radio dari segala arah dengan penguatan (gain) yang sama. Pertimbangannya adalah karena gateway yang akan diletakkan di dekat gedung Laboratorium Teknik Elektro harus dapat menerima pancaran sensor node yang terletak di berbagai lokasi di dalam kampus Politeknik.

Untuk mendapatkan panjang elemen antena, saat ini sudah tersedia beberapa kalkulator online penghitung antena jenis J match dan Slim Jim yang dapat diakses melalui internet. Salah satunya bisa diperoleh di [13]. Parameter yang dimasukkan adalah frekuensi kerja dan velocity factor, yang merupakan kecepatan rambat gelombang radio pada bahan antena. Karena antena dibuat dari kabel antena $300 \mathrm{ohm}$ dengan bahan tembaga, maka velocity factor yang digunakan adalah 0,96. Antena $300 \mathrm{ohm}$ ini dibuat dari kabel pita yang biasa digunakan untuk kabel antena TV lama.

Setelah dihubungkan dengan kabel coaxial, antena dimasukkan dalam pipa PVC $1 / 2$ " untuk menjaganya dari kemasukan air dan terkena debu. Bentuk fisik antena sender $433 \mathrm{MHz}$ dan $915 \mathrm{MHz}$ yang sudah jadi ditunjukkan dalam Gambar 15 dan Gambar 16.

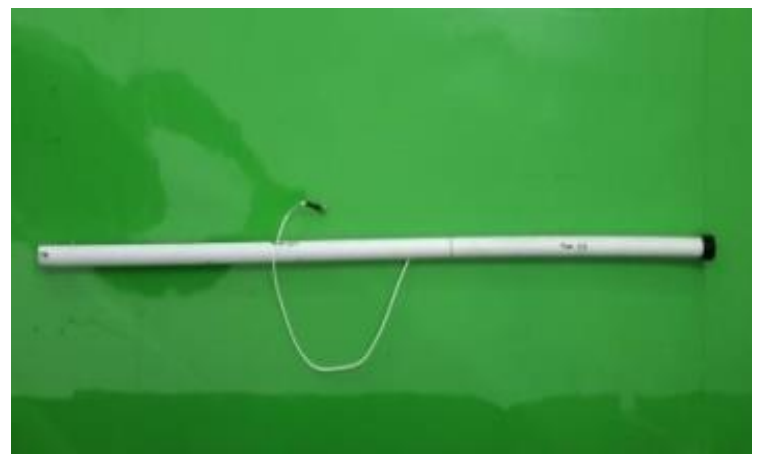

Gambar 15. Bentuk fisik antena sender $433 \mathrm{MHz}$

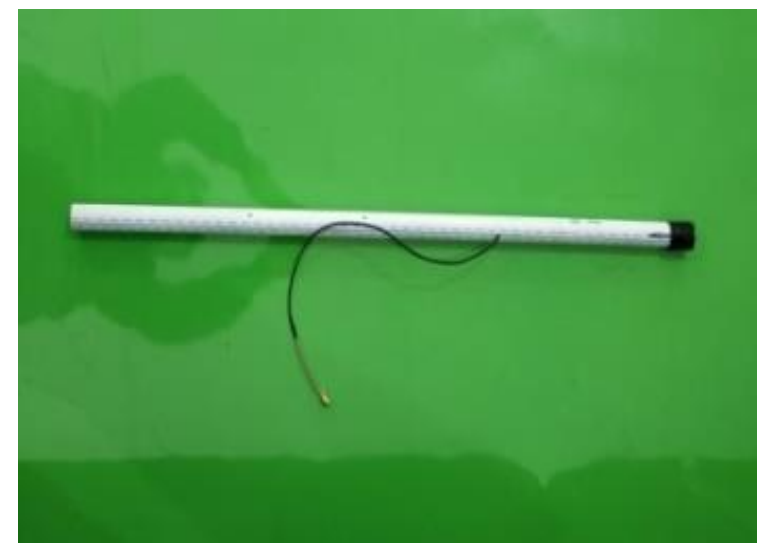

Gambar 16. Bentuk fisik antena sender $915 \mathrm{MHz}$

\section{G. Perancangan Antena Receiver}

Untuk antena receiver, digunakan dua jenis antena agar bisa dibandingkan. Yang pertama adalah rubber duck yang sudah tersedia di Laboratorium Mikroprosesor sehingga tidak perlu dibuat. Antena lainnya adalah antena Yagi-Uda. Karena pola radiasinya yang uni-directional dan tentu mempunyai penguatan lebih besar dibanding antena rubber duck yang mempunyai pola radiasi omni-directional, antena Yagi-Uda perlu digunakan jika sinyal yang diterima oleh antena rubber duck kurang memadai untuk diterima oleh receiver.

Antena Yagi-Uda yang dirancang, mempunyai 5 buah elemen yaitu sebuah reflector, sebuah driven, dan tiga buah director. Susunan ketiganya ditunjukkan dalam Gambar 17.

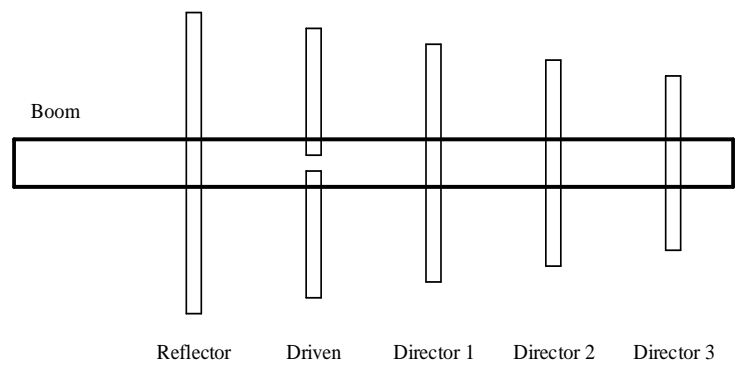

Gambar 17. Sketsa antena Yagi-Uda 5 elemen yang dirancang bangun

Perhitungan tiap elemen dalam Gambar 17 dilakukan seperti berikut. Untuk frekuensi kerja $433 \mathrm{MHz}$ dan $915 \mathrm{MHz}$ digunakan persamaan panjang gelombang, untuk perhitungan antena receiver $915 \mathrm{MHZ}$ juga menggunakan rumus yang sama tetapi perlu mengganti nilai Freq dari 433 menjadi 915.

$$
\text { Lambda }(\lambda)=\frac{C}{\text { Freq }} \times 0,95
$$

Di mana :

$\mathrm{C}=$ adalah kecepatan rambat cahaya di ruang hampa $3.10^{8} \mathrm{~m} / \mathrm{dt}$

$0,95=$ nilai pendekatan cepat rambat pada media aluminium sebagai bahan Antena.

Freq $=$ frekuensi kerja $(\mathrm{MHz})$

Maka untuk frekuensi kerja $433 \mathrm{MHz}$ diperoleh:

$$
\text { Lambda }(\lambda)=\frac{300}{433 \mathrm{MHz}} \times 0,95
$$


Lambda $(\lambda)=0,692840647 \times 0,95$

Lambda $(\lambda)=0,658198615$ Meter

Panjang total elemen driven adalah $1 / 2 \lambda$, maka dengan nilai $\lambda$ sama dengan 0,658198615 meter diperoleh :

$$
\begin{aligned}
1 / 2 \times 0,658198615 \text { meter }= & 0,329099308 \text { meter } \\
& =32,9099308 \text { centimeter } \\
& \approx 33 \text { centimeter }
\end{aligned}
$$

Panjang elemen reflektor diperoleh dengan cara menambahkan $1 / 2 \lambda$ dengan $5 \%$ dari $1 / 2 \lambda$. Karena $1 / 2 \lambda$ sama dengan $33 \mathrm{~cm}$, maka tambahan $5 \%$ adalah sepanjang $33 \times$ $0,05=1,65$. Sehingga panjang elemen reflektor adalah $33+$ $1,65=34,65 \mathrm{~cm}$.

Berbeda dengan reflektor yang panjangnya merupakan penambahan $5 \%$ dari panjang elemen driven sebesar $1 / 2 \lambda$, panjang elemen direktor merupakan pengurangan $5 \%$ dari panjang elemen driven. Sehingga elemen direktor pertama (yang paling dekat dengan elemen driven) mempunyai panjang $33-1,65=31,35 \mathrm{~cm}$. Sementara panjang elemen direktor kedua dan ketiga berturut-turut adalah $31,35-1,65=29,7 \mathrm{~cm}$ dan 29,7 - 1,65 = 28,05 cm. Setelah dibangun, bentuk antena sender $433 \mathrm{MHz}$ dan $915 \mathrm{MHz}$ yang sudah jadi akan tampak seperti pada Gambar 18 dan Gambar 19.

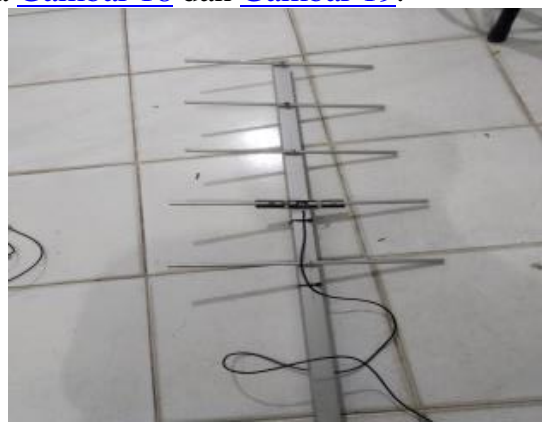

Gambar 18. Bentuk fisik antena Yagi untuk receiver $433 \mathrm{MHz}$

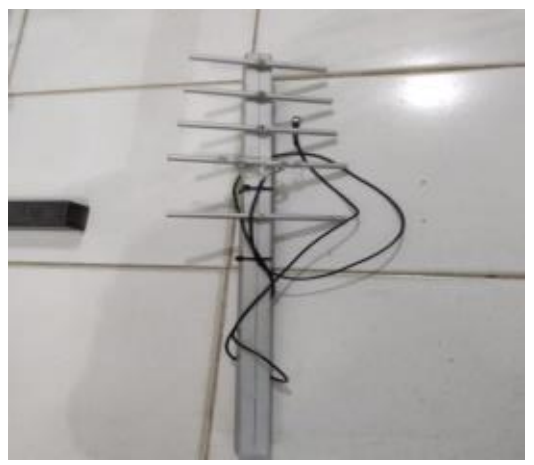

Gambar 19. Bentuk fisik antena Yagi untuk receiver $915 \mathrm{MHz}$

\section{HASIL DAN PEMBAHASAN}

\section{A. Proses Pengukuran}

Setelah selesai proses rancang bangun perangkat pengukuran performa LoRa, maka tahap selanjutnya adalah melakukan pengukuran. Sebelum dilakukan pengukuran, LoRa sender untuk frekuensi $433 \mathrm{MHz}$ dan $915 \mathrm{MHz}$ serta antenanya diletakkan pada tiang setinggi 6 meter seperti ditunjukkan pada Gambar 20.

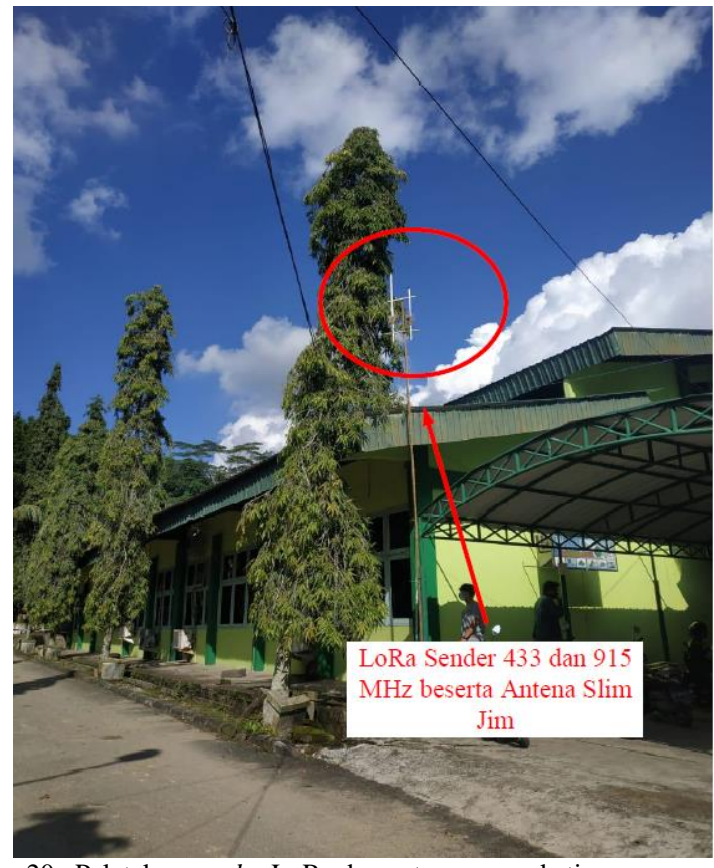

Gambar 20. Peletakan sender LoRa dan antenanya pada tiang

Setelah sender LoRa untuk frekuensi 433 dan $915 \mathrm{MHz}$ diaktifkan, maka keduanya mengirim paket data secara periodik. Panjang payload paket adalah 120 bit, ditambah dengan 20 bit header + CRC header dan 16 bit CRC payload yang sudah disiapkan LoRa. Jeda antar paket adalah 500 mili detik. Setiap paket mempunyai nomor 1 hingga 1000. Setelah mencapai 1000, nomor paket yang dikirim akan kembali ke 1 . Selanjutnya, receiver LoRa dibawa ke lima lokasi yang ditentukan untuk mendapatkan data parameter yang muncul pada display. Jarak antara semua lokasi (dua lokasi dalam satu gedung) dan Laboratorium Teknik Elektro ditunjukkan dalam Gambar 21. Semua lokasi berada dalam gedung. Pengukuran dilakukan selama dua hari dari jam 10:00 hingga 14:00. Pada kedua hari tersebut cuaca cerah berawan.

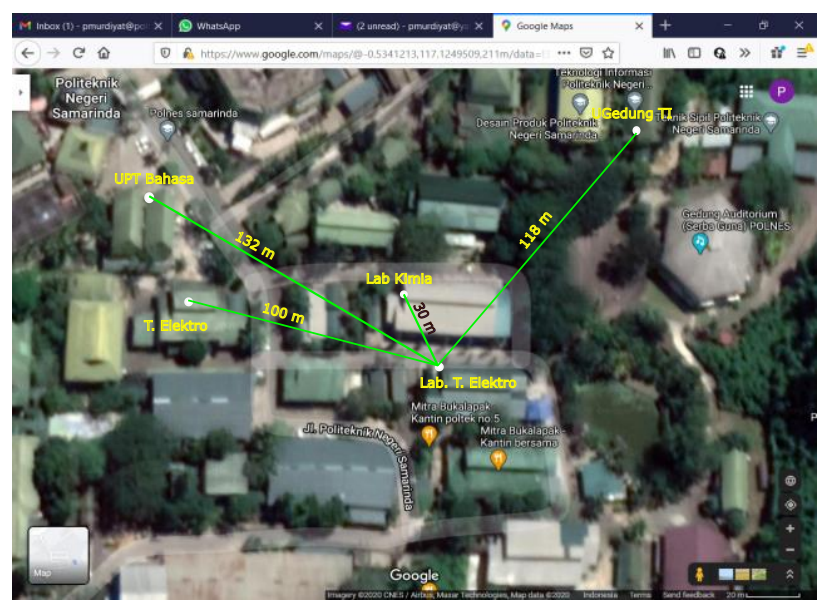

Gambar 21. Jarak antara lokasi pengukuran dengan Laboratorium Teknik Elektro

Parameter yang diukur adalah received signal strength indication (RSSI), signal to noise ratio (SNR), dan packet loss. 
RSSI adalah besar sinyal yang diterima oleh receiver. Satuan yang digunakan adalah decibel $(\mathrm{dB})$. Menurut standar, agar receiver LoRa dapat memproses data yang diterima, nilai minimum RSSI adalah -120 dB [15]. SNR adalah parameter ukur untuk melihat perbandingan antara besar sinyal yang diterima terhadap noise pada receiver. Menurut standar, receiver LoRa mampu memproses paket data jika nilai SNR minimal adalah $-20 \mathrm{~dB}$ [15].

Jika parameter SNR dan RSSI dihasilkan oleh receiver LoRa dengan memberikan perintah tertentu, pengukuran packet loss dilakukan dengan cara menghitung jumlah paket yang diterima. Perhitungan dilakukan tiap 1000 paket dikirim. Packet loss $(P L)$ dihitung dengan persamaan berikut:

$$
\mathrm{PL}(\%)=\frac{1000-\text { jumlah paket yang diterima }}{1000} \times 100
$$

\section{B. Pengujian LoRa $433 \mathrm{MHz}$}

Untuk pengujian LoRa dengan frekuensi kerja $433 \mathrm{MHz}$ hasil data pengujiannya dapat dilihat pada Tabel 4. Dari data pada Tabel 4 dapat dibuat perbandingan antara RSSI, SNR dan PL yang menggunakan antena rubber duck dan yang menggunakan antena Yagi-Uda. Perbandingan untuk RSSI, SNR, dan PL, berturut-turut ditunjukkan dengan grafik pada Gambar 22, Gambar 23, dan Gambar 24.

TABEL 4

DATA HASIL PENGUKURAN PENERIMAAN SINYAL LORA

\begin{tabular}{|c|c|c|c|c|c|c|c|c|}
\hline \multirow[b]{2}{*}{ No } & \multirow[b]{2}{*}{$\begin{array}{c}\text { Lokasi } \\
\text { Panel }\end{array}$} & \multirow[b]{2}{*}{ Hasil } & \multicolumn{3}{|c|}{ Antena Rubber Duck } & \multicolumn{3}{|c|}{ Antena Yagi 5 Elemen } \\
\hline & & & $\begin{array}{l}\text { RSSI } \\
(\mathrm{dB})\end{array}$ & $\begin{array}{l}\text { SNR } \\
(\mathrm{dB})\end{array}$ & $\begin{array}{l}\text { PL } \\
(\%)\end{array}$ & $\begin{array}{l}\text { RSSI } \\
(\mathrm{dB})\end{array}$ & $\begin{array}{l}\text { SNR } \\
(\mathrm{dB})\end{array}$ & $\begin{array}{l}\mathrm{PL} \\
(\%)\end{array}$ \\
\hline \multirow{4}{*}{1} & \multirow{4}{*}{$\begin{array}{l}\text { Jurusan } \\
\text { Elektro }\end{array}$} & Uji 1 & -107 & 4.75 & 0.00 & -101 & 8.50 & 0.20 \\
\hline & & Uji 2 & -107 & 4.75 & 0.00 & -103 & 8.50 & 0.00 \\
\hline & & Uji 3 & -112 & -1.75 & 2.60 & -104 & 8.50 & 0.10 \\
\hline & & $\begin{array}{l}\text { Rata- } \\
\text { Rata }\end{array}$ & $\begin{array}{c}- \\
108.6\end{array}$ & 2.58 & 0.90 & $\begin{array}{c}- \\
102.6 \\
\end{array}$ & 8.50 & 0.10 \\
\hline \multirow{4}{*}{2} & \multirow{4}{*}{$\begin{array}{c}\text { Upt Bahasa } \\
\text { Lantai } 1\end{array}$} & Uji 1 & -113 & 1.50 & 0.20 & -110 & 2.00 & 0.00 \\
\hline & & Uji 2 & -112 & 1.75 & 0.20 & -110 & 2.25 & 0.00 \\
\hline & & Uji 3 & -115 & -4.00 & 0.30 & -109 & 3.25 & 0.10 \\
\hline & & $\begin{array}{l}\text { Rata- } \\
\text { Rata }\end{array}$ & $\overline{113.3}$ & -0.25 & 0.23 & $\begin{array}{c}- \\
109.6\end{array}$ & 2.50 & 0.03 \\
\hline \multirow{4}{*}{3} & \multirow{4}{*}{$\begin{array}{c}\text { Upt Bahasa } \\
\text { Lantai } 2\end{array}$} & Uji 1 & -112 & 4.50 & 0.00 & -116 & 7.00 & 0.10 \\
\hline & & Uji 2 & -111 & 5.50 & 0.20 & -117 & 7.25 & 0.00 \\
\hline & & $\mathrm{Uji} 3$ & -116 & 0.50 & 0.20 & -118 & 5.25 & 0.00 \\
\hline & & $\begin{array}{l}\text { Rata- } \\
\text { Rata }\end{array}$ & -113 & 3.50 & 0.13 & -117 & 6.50 & 0.03 \\
\hline \multirow{4}{*}{4} & \multirow{4}{*}{ Lab Kimia } & Uji 1 & -95 & 8.75 & 0.00 & -104 & 8.50 & 0.10 \\
\hline & & Uji 2 & -99 & 8.50 & 0.00 & -102 & 8.75 & 0.30 \\
\hline & & Uji 3 & -96 & 8.25 & 0.00 & -106 & 8.50 & 0.30 \\
\hline & & $\begin{array}{l}\text { Rata- } \\
\text { Rata } \\
\end{array}$ & -96.6 & 8.50 & 0,00 & -104 & 8.58 & 0.23 \\
\hline \multirow{4}{*}{5} & \multirow{4}{*}{$\begin{array}{l}\text { Teknologi } \\
\text { Informasi }\end{array}$} & Uji 1 & -110 & 1.00 & 0.00 & -113 & 5.75 & 0.40 \\
\hline & & Uji 2 & -107 & 5.00 & 0.00 & -110 & 6.00 & 0.20 \\
\hline & & Uji 3 & -112 & -2.00 & 0.00 & -110 & 5.75 & 0.00 \\
\hline & & $\begin{array}{l}\text { Rata- } \\
\text { Rata } \\
\end{array}$ & $\begin{array}{c}- \\
109.6 \\
\end{array}$ & 1.33 & 0.00 & -111 & 5.83 & 0.20 \\
\hline
\end{tabular}
PADA FREKUENSI $433 \mathrm{MHz}$

Pada Gambar 22 dapat dilihat bahwa pada umumnya semua nilai RSSI masih berada di atas nilai RSSI minimum LoRa (-120 dB), dengan hasil pengukuran terkecil sebesar -117 dB. Hal ini menunjukkan bahwa link antara receiver LoRa di seluruh lokasi tersebut dengan sender LoRa yang diletakkan di gedung Laboratorium Teknik Elektro memenuhi syarat untuk komunikasi data.
Dari Gambar 22 juga ditunjukkan bahwa RSSI yang dihasilkan kedua jenis antena juga bervariasi, walaupun secara teoritis RSSI yang dihasilkan oleh antena Yagi-Uda seharusnya lebih kecil mengingat penguatannya yang lebih tinggi dibanding antena rubber duck. Kemungkinan hal ini disebabkan oleh lingkungan dalam gedung dan arah antena yang kurang tepat. Jika nilai RSSI tidak terlalu jauh, penggunaan antena rubber duck lebih direkomendasikan karena ukurannya yang lebih kecil, instalasinya yang lebih mudah, dan secara estetika tampak lebih rapi.

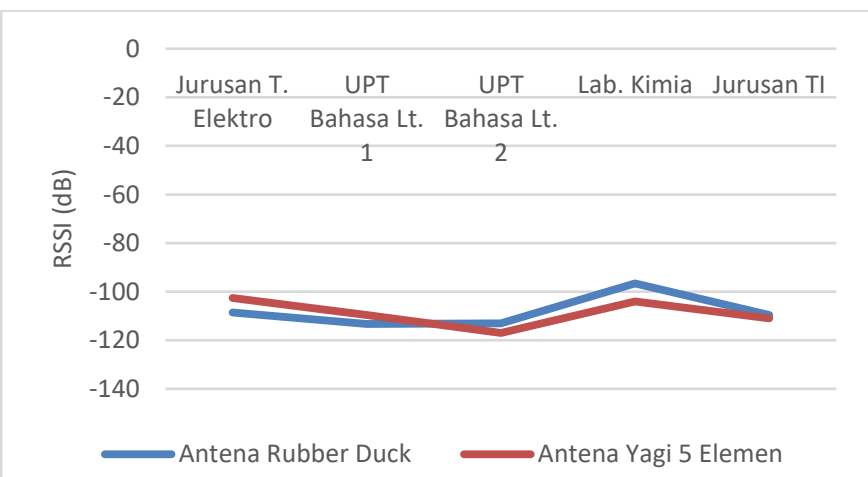

Gambar 22. Perbandingan RSSI yang diperoleh receiver dengan menggunakan antena rubber duck dan Yagi-Uda pada frekuensi $433 \mathrm{MHz}$

Untuk perbandingan SNR yang diperoleh antena rubber duck dan Yagi-Uda, grafiknya ditunjukkan dalam Gambar 23. Karena nilai rata-rata SNR untuk semua lokasi baik dengan menggunakan antena Yagi-Uda dan rubber duck di atas -20 $\mathrm{dB}$, maka hasilnya masih memenuhi persyaratan system komunikasi yang baik. Nilai SNR terendah sebesar $-0,25 \mathrm{~dB}$ masih sangat jauh dari SNR yang disyaratkan pada LoRa.

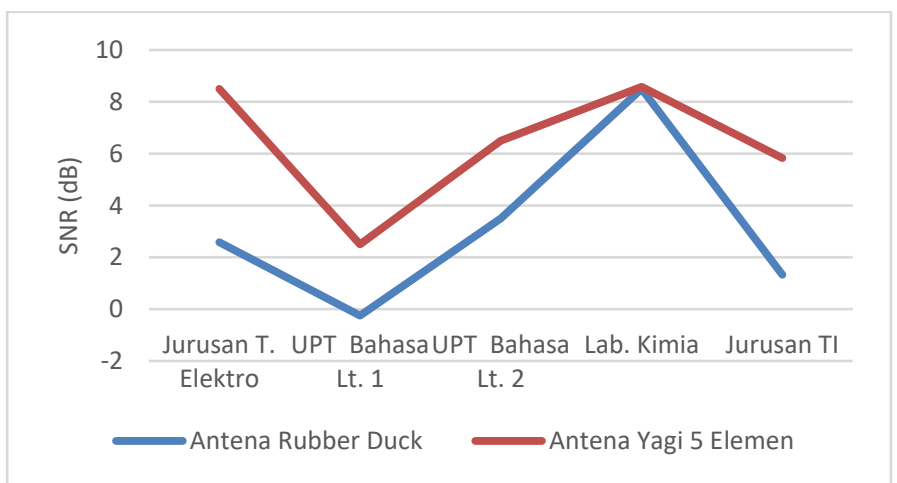

Gambar 23. Perbandingan SNR yang diperoleh receiver dengan menggunakan antena rubber duck dan Yagi-Uda pada frekuensi $433 \mathrm{MHz}$ 


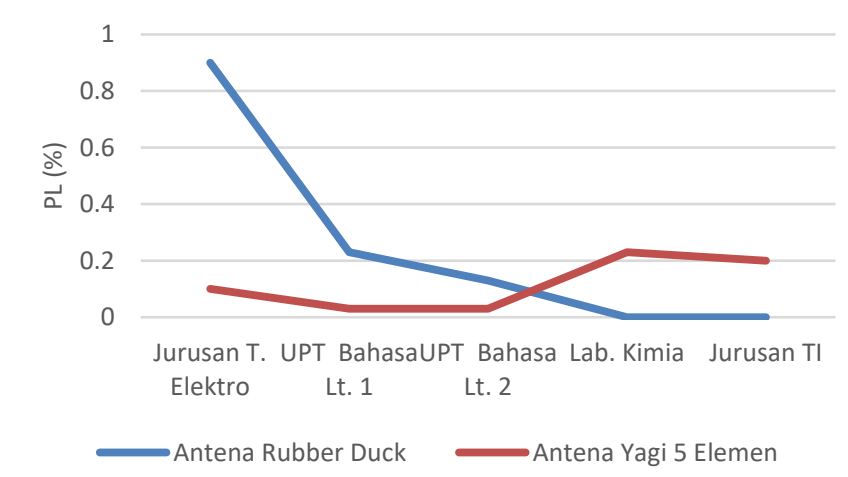

Gambar 24. Perbandingan PL yang diperoleh receiver dengan menggunakan antena rubber duck dan Yagi-Uda pada frekuensi $433 \mathrm{MHz}$

Parameter pengujian yang ketiga adalah PL, yang grafik perbandingannya ditunjukkan dalam Gambar 24. Grafik menujukkan bahwa seluruh PL yang berada di bawah $1 \%$ yang berarti bahwa kualitas transmisi data menurut Tabel 1 tergolong bagus karena masih di bawah $3 \%$. Dengan PL terbesar yang hanya mencapai $0,9 \%$, maka kemungkinan kehilangan paket masih sangat kecil.

\section{Pengujian LoRa $915 \mathrm{MHz}$}

Untuk pengujian LoRa dengan frekuensi kerja $915 \mathrm{MHz}$ hasil data pengujiannya dapat dilihat pada Tabel 5. Dari data pada Tabel 5 dapat dibuat perbandingan antara RSSI, SNR dan PL yang diterima dengan menggunakan antena rubber duck dan antena Yagi-Uda. Perbandingan untuk RSSI, SNR, dan PL, berturut-turut ditunjukkan dalam grafik pada Gambar 25, Gambar 26, dan Gambar 27.

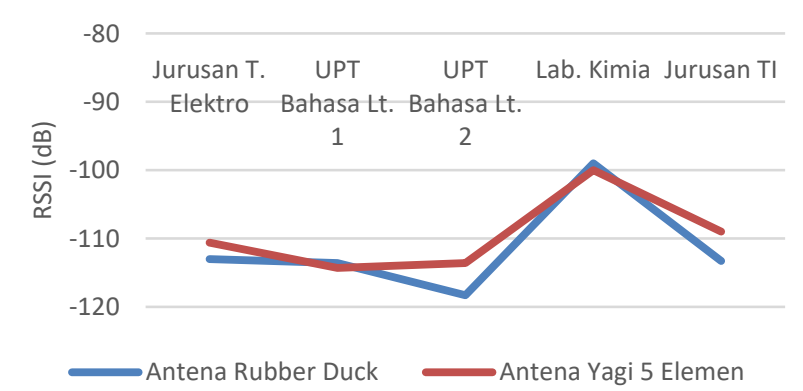

Gambar 25. Perbandingan RSSI yang diperoleh receiver dengan menggunakan antena rubber duck dan Yagi-Uda pada frekuensi $915 \mathrm{MHz}$

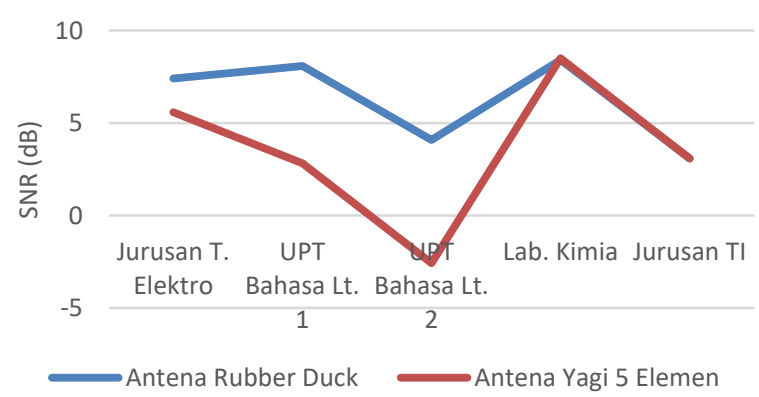

Gambar 26. Perbandingan SNR yang diperoleh receiver dengan menggunakan antena rubber duck dan Yagi-Uda pada frekuensi $915 \mathrm{MHz}$

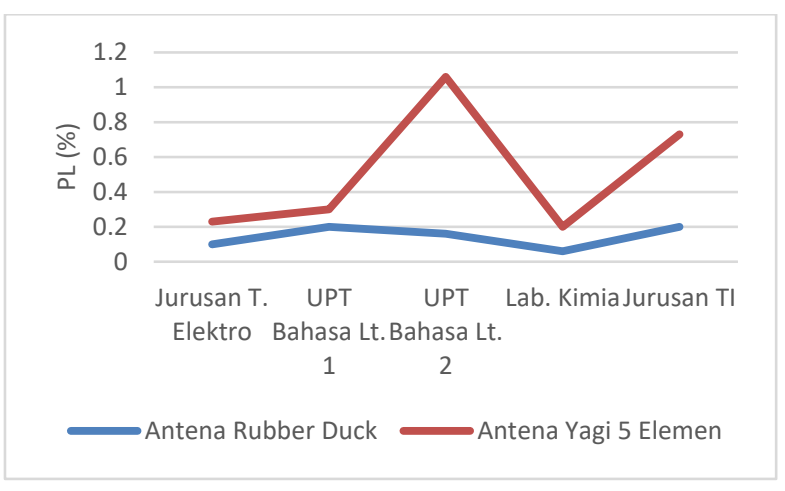

Gambar 27. Perbandingan PL yang diperoleh receiver dengan menggunakan antena rubber duck dan Yagi-Uda pada frekuensi $915 \mathrm{MHz}$

Pada Gambar 25 tampak bahwa semua nilai RSSI masih berada di atas $-120 \mathrm{~dB}$, dan nilai terkecil dari hasil pengukuran adalah -118 dB. Hal ini menunjukkan bahwa link antara receiver LoRa di seluruh lokasi tersebut dan sender LoRa yang diletakkan di gedung Laboratorium Jurusan Teknik Elektro masih memenuhi syarat melakukan komunikasi data dengan LoRa.

Selisih nilai RSSI yang dihasilkan kedua antena tidak terlalu berbeda jauh, sehingga penggunaan antena rubber duck yang berukuran kecil, tidak memakan tempat, dan lebih rapi secara estetika, direkomendasikan. Namun untuk gedung UPT Bahasa di lantai 2, dengan selisih yang cukup dekat dengan $120 \mathrm{~dB}$, pemilihan antena dengan penguatan gain yang lebih besar sangat direkomendasikan. Penggunaan antena unidirectional seperti Yagi-Uda menunjukkan peningkatan RSSI yang signifikan.

TABEL 5

DATA HASIL PENGUKURAN PENERIMAAN SINYAL LORA PADA FREKUENSI $915 \mathrm{MHz}$

\begin{tabular}{|c|c|c|c|c|c|c|c|c|}
\hline \multirow[b]{2}{*}{ No } & \multirow{2}{*}{$\begin{array}{l}\text { Lokasi } \\
\text { Panel }\end{array}$} & \multirow[b]{2}{*}{ Hasil } & \multicolumn{3}{|c|}{ Antena Rubber Duck } & \multicolumn{3}{|c|}{ Antena Yagi 5 Elemen } \\
\hline & & & $\begin{array}{c}\text { RSSI } \\
(\mathrm{dB})\end{array}$ & $\begin{array}{l}\text { SNR } \\
(\mathrm{dB})\end{array}$ & $\begin{array}{l}\text { PL } \\
(\%)\end{array}$ & $\begin{array}{c}\text { RSSI } \\
(\mathrm{dB})\end{array}$ & $\begin{array}{l}\text { SNR } \\
(\mathrm{dB})\end{array}$ & $\begin{array}{l}\text { PL } \\
(\%)\end{array}$ \\
\hline \multirow{4}{*}{1} & \multirow{4}{*}{$\begin{array}{l}\text { Jurusan } \\
\text { Elektro }\end{array}$} & Uji 1 & -113 & 7.00 & 0.00 & -111 & 5.25 & 0.10 \\
\hline & & Uji 2 & -113 & 7.50 & 0.20 & -111 & 5.25 & 0.20 \\
\hline & & Uji 3 & -113 & 7.75 & 0.10 & -110 & 6.25 & 0.40 \\
\hline & & $\begin{array}{l}\text { Rata- } \\
\text { Rata }\end{array}$ & -113 & 7.41 & 0.10 & $\begin{array}{c}- \\
110.6\end{array}$ & 5.58 & 0.23 \\
\hline \multirow{4}{*}{2} & \multirow{4}{*}{$\begin{array}{c}\text { Upt Bahasa } \\
\text { Lantai } 1\end{array}$} & Uji 1 & -114 & 8.25 & 0.10 & -115 & 3.75 & 0.50 \\
\hline & & Uji 2 & -113 & 8.00 & 0.20 & -114 & 1.75 & 0.10 \\
\hline & & Uji 3 & -114 & 8.00 & 0.30 & -114 & 3.00 & 0.30 \\
\hline & & $\begin{array}{l}\text { Rata- } \\
\text { Rata }\end{array}$ & $\begin{array}{c}- \\
113.6\end{array}$ & 8.08 & 0.20 & 114.3 & 2.83 & 0.30 \\
\hline \multirow{4}{*}{3} & \multirow{4}{*}{$\begin{array}{c}\text { Upt Bahasa } \\
\text { Lantai } 2\end{array}$} & Uji 1 & -118 & 4.50 & 0.10 & -114 & -2.75 & 0.40 \\
\hline & & Uji 2 & -118 & 4.75 & 0.20 & -114 & -5.25 & 1.80 \\
\hline & & Uji 3 & -119 & 3.00 & 0.20 & -113 & 0.25 & 1.00 \\
\hline & & $\begin{array}{l}\text { Rata- } \\
\text { Rata }\end{array}$ & $\begin{array}{c}- \\
118.3\end{array}$ & 4.08 & 0.16 & $\begin{array}{c}- \\
113.6\end{array}$ & -2.58 & 1.06 \\
\hline \multirow{4}{*}{4} & \multirow{4}{*}{ Lab Kimia } & Uji 1 & -99 & 8.50 & 0.20 & -100 & 8.75 & 0.10 \\
\hline & & Uji 2 & -99 & 8.25 & 0.00 & -101 & 8.25 & 0.10 \\
\hline & & Uji 3 & -99 & 8.50 & 0.00 & -99 & 8.50 & 0.40 \\
\hline & & $\begin{array}{l}\text { Rata- } \\
\text { Rata }\end{array}$ & -99 & 8.41 & 0,06 & -100 & 8.50 & 0.20 \\
\hline \multirow{4}{*}{5} & \multirow{4}{*}{$\begin{array}{l}\text { Teknologi } \\
\text { Informasi }\end{array}$} & Uji 1 & -113 & 3.75 & 0.10 & -107 & -2.25 & 0.80 \\
\hline & & Uji 2 & -113 & 3.75 & 0.40 & -110 & 5.50 & 1.20 \\
\hline & & Uji 3 & -114 & 1.75 & 0.10 & -110 & 6.00 & 0.20 \\
\hline & & $\begin{array}{l}\text { Rata- } \\
\text { Rata }\end{array}$ & $\begin{array}{c}- \\
113.3\end{array}$ & 3.08 & 0.20 & -109 & 3.08 & 0.73 \\
\hline
\end{tabular}

Untuk nilai SNR yang dihasilkan, tampak pada Gambar $\underline{25}$, semuanya masih di atas $-20 \mathrm{~dB}$, yang menunjukkan bahwa

Submitted: 16/12/2020; Revised: 17/12/2020;

Accepted: 22/12/2020; Online first: 31/12/2020

http://dx.doi.org/10.46964/poligrid.v1i2.602 
kualitas komunikasi antara sender dan receiver masih baik. Nilai SNR terkecil sebesar -2,58 dB yang dihasilkan oleh YagiUda masih cukup jauh dari $-20 \mathrm{~dB}$, sehingga sinyal informasinya masih bisa dibedakan dari sinyal noise yang ada.

Parameter pengujian yang ketiga adalah PL, yang grafik perbandingannya ditunjukkan dalam Gambar 27. Tampak bahwa semua nilai SNR berada di bawah $3 \%$ yang artinya, menurut Tabel 1, kualitasnya tergolong bagus. PL tertinggi yang terjadi ketika menggunakan antena penerima berupa antena Yagi-Uda mencapai 1,06 \% yang masih cukup jauh dari $3 \%$.

TABEL 6

PERBANDINGAN HASIL PENERIMAAN LORA PADA FREKUENSI $433 \mathrm{MHz}$ DAN $915 \mathrm{MHz}$

\begin{tabular}{|c|c|c|c|c|c|c|c|c|}
\hline \multirow[b]{2}{*}{ No } & \multirow[b]{2}{*}{$\begin{array}{l}\text { Lokasi } \\
\text { Panel }\end{array}$} & \multirow[b]{2}{*}{ Hasil } & \multicolumn{3}{|c|}{ Antena Rubber Duck } & \multicolumn{3}{|c|}{ Antena Yagi 5 Elemen } \\
\hline & & & $\begin{array}{l}\text { RSSI } \\
(\mathrm{dB})\end{array}$ & $\begin{array}{l}\text { SNR } \\
(\mathrm{dB})\end{array}$ & $\begin{array}{l}\text { PL } \\
(\%)\end{array}$ & $\begin{array}{l}\text { RSSI } \\
(\mathrm{dB})\end{array}$ & $\begin{array}{l}\text { SNR } \\
(\mathrm{dB})\end{array}$ & $\begin{array}{l}\mathrm{PL} \\
(\%)\end{array}$ \\
\hline \multirow[t]{2}{*}{1} & \multirow{2}{*}{$\begin{array}{l}\text { Jurusan } \\
\text { Elektro }\end{array}$} & 433 & $\begin{array}{c}- \\
108.6 \\
\end{array}$ & 2.58 & 0.90 & $\begin{array}{c}- \\
102.6 \\
\end{array}$ & 8.50 & 0.10 \\
\hline & & 915 & -113 & 7.41 & 0.10 & $\begin{array}{c}- \\
110.6\end{array}$ & 5.58 & 0.23 \\
\hline \multirow[t]{2}{*}{2} & \multirow{2}{*}{$\begin{array}{c}\text { Upt } \\
\text { Bahasa } \\
\text { Lantai } 1\end{array}$} & 433 & $\begin{array}{c}- \\
113.3 \\
\end{array}$ & $0 . \overline{25}$ & 0.23 & $\begin{array}{c}- \\
109.6 \\
\end{array}$ & 2.50 & 0.03 \\
\hline & & 915 & $\begin{array}{c}- \\
113.6\end{array}$ & 8.08 & 0.20 & $\begin{array}{c}- \\
114.3\end{array}$ & 2.83 & 0.30 \\
\hline \multirow[b]{2}{*}{3} & \multirow{2}{*}{$\begin{array}{c}\text { Upt } \\
\text { Bahasa } \\
\text { Lantai } 2\end{array}$} & 433 & -113 & 3.50 & 0.13 & -117 & 6.50 & 0.03 \\
\hline & & 915 & $\begin{array}{c}- \\
118.3\end{array}$ & 4.08 & 0.16 & $\begin{array}{c}- \\
113.6\end{array}$ & $\begin{array}{c}- \\
2.58\end{array}$ & 1.06 \\
\hline \multirow{2}{*}{4} & \multirow{2}{*}{ Lab Kimia } & 433 & -96.6 & 8.50 & 0,00 & -104 & 8.58 & 0.23 \\
\hline & & 915 & -99 & 8.41 & 0,06 & -100 & 8.50 & 0.20 \\
\hline \multirow{2}{*}{5} & \multirow{2}{*}{$\begin{array}{l}\text { Teknologi } \\
\text { Informasi }\end{array}$} & 433 & $\begin{array}{c}- \\
109.6 \\
\end{array}$ & 1.33 & 0.00 & -111 & 5.83 & 0.20 \\
\hline & & 915 & $\begin{array}{c}- \\
113.3 \\
\end{array}$ & 3.08 & 0.20 & -109 & 3.08 & 0.73 \\
\hline
\end{tabular}

Selain mengamati kelayakan link yang dibangun oleh sender dan recever LoRa dengan menggunaan antenna-antena tertentu, dapat juga dibuat perbandingan parameter antara LoRa dengan frekuensi $433 \mathrm{MHz}$ dan $915 \mathrm{MHz}$. Hasilnya ditunjukkan dalam Tabel 6.

Berdasarkan Tabel 6, $70 \%$ hasil pengukuran RSSI menunjukkan bahwa nilai RSSI pada $433 \mathrm{MHz}$ lebih rendah dibanding nilai RSSI pada frekuensi $915 \mathrm{MHz} .30 \%$ nilai pengukuran RSSI yang lebih rendah pada frekuensi $915 \mathrm{MHz}$ kemungkinan terjadi karena arah antena Yagi-Uda yang tidak tepat.

Untuk SNR, antenna rubber duck pada umumnya menghasilkan nilai SNR yang tinggi pada frekuensi $915 \mathrm{MHz}$, sedang antenna Yagi-Uda menghasilkan nilai SNR yang lebih tinggi pada frekuensi $433 \mathrm{MHz}$. Hal ini kemungkinan disebabkan oleh tingginya noise eksternal di sekitar receiver pada frekuensi $433 \mathrm{MHz}$.

Selanjutnya, juga diketahui bahwa $70 \%$ hasil pengukuran PL pada frekuensi $433 \mathrm{MHz}$ menunjukkan kehilangan paket yang lebih rendah dibanding PL yang dihasilkan pada frekuensi $915 \mathrm{MHz}$.

Maka, penggunaan frekuensi $433 \mathrm{MHz}$ untuk LoRa pada umumnya memberikan hasil lebih baik. Akan tetapi karena Peraturan Menteri Kominfo sudah menetapkan penggunaan LoRa pada frekuensi $915 \mathrm{MHz}$, maka frekuensi ini pula yang akan digunakan pada system monitoring yang sedang dibangun.

\section{KESIMPULAN}

Setelah melakukan perancangan, pembuatan alat dan serangkaian pengukuran di lokasi titik uji dapat disimpulkan bahwa:

1). Dengan memperhatikan hasil ukur parameter RSSI, SNR, dan PL, teknologi LoRa baik menggunakan frekuensi 433 $\mathrm{MHz}$ maupun frekuensi $915 \mathrm{MHz}$ layak untuk digunakan sebagai jaringan komunikasi system monitoring di kampus Politeknik Negeri Samarinda.

2). Secara umum, nilai RSSI dan PL yang dihasilkan oleh LoRa pada frekuensi $433 \mathrm{MHz}$ lebih baik dibanding pada frekuensi $915 \mathrm{MHz}$.

3). Nilai SNR yang dihasilkan pada frekuensi $433 \mathrm{MHZ}$ lebih tinggi dibanding frekuensi $915 \mathrm{MHz}$ jika digunakan antena Yagi-Uda, namun sebaliknya, SNR pada frekuensi $915 \mathrm{MHz}$ lebih tinggi dibanding pada frekuensi $433 \mathrm{MHz}$ jika digunakan antena rubber duck.

\section{REFERENSI}

[1] J. Petäjäjärvi, K. Mikhaylov, A. Roivainen, T. Hänninen, dan M. Pettissalo, "On the coverage of LPWANs: Range evaluation and channel attenuation model for LoRa technology", Prosiding The $14^{\text {th }}$ International Conference on ITS Telecommunication 2015(ITST 2015), Copenhagen, Denmark, Dec. 2- 42015.

[2] LoRa Alliance, A technical overview of LoRa ${ }^{\circledR}$ and LoRaWAN ${ }^{\mathrm{TM}}$, San Ramon, California, 2015.

[3] P. Devi, D. Istianti, S.Y. Prawiro, N. Bogi, A. Karna, dan I. A. Nursafa, "Analisis performansi teknologi akses LPWAN LoRa Antares untuk komunikasi data end node", Prosiding The 11 Conference on Informtaion Technology and Electrical Engineering 2019 (CITEE 2019), Yogyakarta, Indonesia, Jul. 24-25 2019.

[4] H. Arijuddin, A. Bhawiyuga, dan K. Amron, "Pengembangan sistem perantara pengiriman data menggunakan modul komunikasi LoRa dan protokol MQTT pada wireless sensor network", Jurnal Pengembangan Teknologi Informasi dan Ilmu Komputer Vol. 3 No. 2 (JPTIIK), Jan. 2019.

[5] F.N. Aroeboesman, M.H.H. Ichsan, R. Primananda, "Analisis kinerja LoRa SX1278 menggunakan topologi star berdasarkan jarak dan besar data pada WSN ", Jurnal Pengembangan Teknologi Informasi dan Ilmu Komputer Vol. 3 No. 4 (JPTIIK), Jan. 2019.

[6] E. Murdyantoro, I. Rosyadi, dan H. Septian, "Studi performansi jarak jangkauan LoRa OLG01 sebagai infrastruktur konektivitas nirkabel IoT", Jurnal Dinamika Rekayasa Vol. 15 No. 1, pp. 47-56, 2019.

[7] A.F. Isnawati, I. Susanto, dan R.A. Purwanita, "Analisis jarak terhadap redaman, SNR (Signal To Noise Ratio), dan kecepatan download pada jaringan ADSL ", Jurnal Infotel Vol. 2 No. 2, Nov. 2010.

[8] H. Fahmi, "Analisis QoS (Quality of Service) pengukuran delay, jitter, packet lost dan throughput untuk mendapatkan kualitas kerja kerja radio streaming yang baik", Jurnal Teknolgi Informasi dan Komunikasi Vol. 7 No. 2, pp. 98-105, Dec. 2018.

[9] A. Malik, L.M. F. Aksara, dan M. Yamin, "Perbandingan metode simple queues dan queues tree untuk optimasi manajemen bandwidth menggunakan Mikrotik (Studi kasus: Pengadilan tinggi agama Kendari)", Jurnal Semantik Vol. 3 No. 2, 2017.

[10] Arduino. [Online]. https:www.arduino.cc.

[11] K. Ch. S. Kavya, S. K. Kotamraju, dan S. Sukumar, "Comparative analysis of Slim Jim antenna for ham radio applications", ARPN Journal of Engineering and Applied Sciences Vol. 9 No. 10, Oct. 2014.

[12] F. Thalib dan M. P.A. Panggabean, "Perancangan dan realisasi antena Yagi empat elemen untuk frekuensi kerja $142 \mathrm{MHz}$, Prosiding Seminar Nasional Teknoin 2010, Yogyakarta, Dec. 112010. 
[13] G.P. Robinson, Antenna Synthesys Through Characteristic Modal Analysis For Small Unmanned Aerial System Application, Thesis, University of Oklahoma, 2019.

[14] MOUKD, Slim Jim And J Pole Calculator, [Online], https://m0ukd.com/calculators/slim-jim-and-j-pole-calculator.

[15] Technical Marketing Workgroup, LoRaWAN, What Is It? A Technical Overview of LoRa and LoRaWAN, White paper, LoRa Alliance, Nov. 2015. 